\section{Management of Irrigation for Vegetables: Past, Present, and Future}

\author{
Salvadore J. Locascio
}

ADDITIONAL INDEX WORDS. subsurface irrigation, gravity-flow irrigation, sprinkler irrigation, microirrigation

\begin{abstract}
SUMmARY. Vegetables are grown throughout the U.S. on various soil types and in various climates. Irrigation is essential to supplement rainfall in all areas to minimize plant water stress. In the U.S., irrigated vegetable production accounts for about 1.9 million ha or $7.5 \%$ of the irrigated area. California, Florida, Idaho, Washington, Texas, Nebraska, Oregon, Wisconsin, and Arizona account for $80 \%$ of the U.S. production of irrigated vegetables. In the U.S., surface and subsurface (seepage) irrigation systems were used initially and are currently used on $45 \%$ of all irrigated crops with a water use efficiency of $33 \%$. Sprinkler or overhead irrigation systems were developed in the 1940s and are currently used extensively throughout the vegetable industry. Sprinkler systems are used on $50 \%$ of the irrigated crop land and have a water use efficiency of $75 \%$. In the late 1960s, microirrigation (drip or trickle) systems were developed and have slowly replaced many of the sprinkler and some of the seepage systems. Microirrigation is currently used on $\mathbf{5 \%}$ of irrigated crops. This highly efficient water system $(90 \%$ to $95 \%)$ is widely used on high value vegetables, particularly polyethylenemulched tomato (Lycopersicon esculentum), pepper (Capsicum annuиm), eggplant (Solanum melongena), strawberry (Fragaria $\times$ ananassa), and cucurbits. Some advantages of drip irrigation over sprinkler include reduced water use, ability to apply fertilizer with the irrigation, precise water distribution, reduced foliar diseases, and the ability to electronically schedule irrigation on large areas with relatively smaller pumps. Drip systems also can be used as subsurface drip systems placed at a depth of 60 to $90 \mathrm{~cm}$. These systems are managed to control the water table, similar to that accomplished with subsurface irrigation systems, but with much greater water use efficiency. Future irrigation concerns include continued availability of water for agriculture, management of nutrients to minimize leaching, and continued development of cultural practices that maximize crop production and water use efficiency.
\end{abstract}

$\mathrm{V}$ egetables are grown extensively throughout the U.S. on various soil types and in different climates. Soils vary from coarse textured sandy soil with a water holding capacity of $8 \%$ to $15 \%$ to fine textured silt and clay soils with water holding capacities of over $40 \%$. Organic soils are used extensively along with gravel and rock soils. Climatic conditions vary from arid regions with little rainfall, such as in California, Arizona, and parts of Texas, to humid regions with substantial rainfall, including Florida, Louisiana, and Georgia (Nonnecke, 1989). In all areas where commercial vegetables are grown, irrigation is essential to supplement rainfall to minimize plant water stress. To produce the maximum yield of high

Horticultural Sciences Department, University of Florida, Gainesville, FL 32611-0690.

Florida Agricultural Experiment Station Journal Series No. R-09734. quality vegetables, an adequate supply of water is essential throughout the plant growth cycle. Water stress due to inadequate water supply or the use of saline water results in reduced plant growth and loss of produce quality. Vegetable growth is reduced by water stress, and yield response to irrigation can be over 200\% (Doss et al., 1980; Locascio and Myers, 1974).

In the U.S., 25.5 million ha of crop land are irrigated. Field corn ( $\mathrm{Zea}$ mays), grains, and pasture account for 13.4 million ha and irrigated vegetable production accounts for about 1.9 million ha [including 0.45 million ha potato (Solanum tuberosum)] or $7.5 \%$ of the irrigated area. Irrigation is es- sential in arid California where 31\% (591,000 ha) of irrigated vegetables are produced as well as in humid Florida. In the U.S., Florida is second to California in vegetable value with $7 \%(130,000$ ha) of the irrigated vegetables. Other states with major irrigated vegetable areas are Idaho (170,000 ha including 159,000 ha potato), Washington ( 163,000 ha including 71,000 ha potato), Texas (112,000 ha), Nebraska (94,000 ha), Oregon (74,000 ha), Wisconsin (72,000 ha), and Arizona $(60,000 \mathrm{ha})$. These nine states account for $80 \%$ of the U.S. production of irrigated vegetables (Irrigation Journal, 2001).

Water for irrigation of all crops, parks, and golf courses is obtained from ground $(37 \%)$ and surface $(63 \%)$ water sources and account for $81 \%$ of the consumptive water use in the U.S. and over $90 \%$ in most western states (Solley et al., 1998). Without irrigation, crop production would not be possible in many areas in the U.S. and would be uneconomical in most areas. Although the U.S. has an abundant supply of fresh water, the demand for urban and industrial uses will continue to increase and result in increased cost of water and competition for irrigation water (Gollelhon et al., 2002). A serious concern of producers will be to maintain an adequate water supply at an affordable cost.

In some areas, water is limited and the amount of water available determines the cultural practices used and the amount of a crop that can be grown. Short-term droughts often result in a decrease in the availability of surface water available for agriculture. With increased pumping, salt water intrusion into wells is a concern in some areas (Myhre et al., 1986). As rural populations continue to decrease, the urban majority will need more water and this competition for water for irrigation will result in increased water costs. To continue to be profitable, commercial agriculture must continue to increase irrigation efficiency. Vegetable irrigation practices of the past, present, and future are presented.

\begin{tabular}{llll}
$\begin{array}{l}\text { Units } \\
\text { To convert U.S. to SI, } \\
\text { multiply by }\end{array}$ & U.S. unit & SI unit & $\begin{array}{l}\text { To convert SI to U.S., } \\
\text { multiply by }\end{array}$ \\
\hline 0.4047 & acre(s) & ha & 2.4711 \\
1 & cbar & $\mathrm{kPa}$ & 1 \\
2.5400 & inch(es) & $\mathrm{cm}$ & 0.3937
\end{tabular}




\section{Surface and subsurface irrigation}

In the U.S. and around the world, surface and subsurface (seepage) irrigation systems were historically used and are currently used on $45 \%$ of all irrigated crops in the U.S. (Gollehon et al., 2002). These systems, often called gravity-flow systems, require an abundance of water, gently sloping fields, and the presence of an impervious soil layer at $50-$ to $90-\mathrm{cm}$ soil depth to maintain the water in the plant root zone. Water is surface applied in lateral ditches or underground conduits. Large quantities of water must be applied to maintain a water table at 50 to $60 \mathrm{~cm}$ below the crop and this results in low water use efficiency (Smajstrla et al., 1999). With continued pumping of water in some areas, salt intrusion becomes a problem. With use of poorer quality water, salts accumulate on the soil surface and as the season progresses, salinity reduces plant growth (Bernstein and Francois, 1973).

Seepage systems are less expensive to install and generally are simpler to manage than other systems. However, $5 \%$ to $10 \%$ of the crop land area is needed for surface ditches needed to transport water to and from the field, and these systems have a water use efficiency of about $33 \%$ or lower. In numerous studies, crop yields of tomato (Doss et al., 1980; Pitts et al., 1988), muskmelon (Cucumis melo) (Bogle and Hartz, 1986), onions ( $A l$ lium cepa) (Ellis et al., 1986), potato, and lettuce (Lactuca sativa) (Sammis 1980) irrigated with seepage irrigation were similar to yields with other irrigation methods. With seep irrigated tomato, water use from $47 \mathrm{~cm}$ (Doss et al., 1980) to $225 \mathrm{~cm}$ (Pitts et al., 1988) have been reported. In the latter study, $80 \%$ of the irrigation water was estimated to have been run-off and percolation downward into the groundwater.

Seepage irrigation systems provide crop production that is equal to that with other irrigation systems, at a relative lower cost (Prevatt et al., 1981), and will continue to be widely used except in areas were water shortages exist and water is expensive. With careful application of water and recycling of tail waters, use efficiencies can be increased (Smajstrla et al., 1984).

\section{Sprinkler irrigation}

In the 1940s, sprinkler or overhead irrigation systems were developed and are currently used extensively throughout the vegetable industry. Sprinkler systems include solid-set systems, center pivot systems, lateral moving systems, and portable and traveling gun systems. Sprinkler irrigation is used on $50 \%$ of the irrigated crop land in the U.S. (Irrigation Journal, 2001). Water is conveyed to the field by conduits and applied through overhead nozzles to the crop. A high degree of water application uniformity can be obtained by overlapping the water pattern. These systems are more costly to purchase and operate, and are more complex to manage than seepage systems. However, they provide better water use efficiency (about 75\%), and control water applications throughout the field (Smajstrla et al., 1999). Water is typically applied on a 5- to 7-d schedule to bring the soil to field capacity in the plant root zone with 38 to 50 $\mathrm{cm}$ of water applied in a typical season for tomato (Locascio et al., 1982). In contrast to surface and subsurface systems, sprinkler systems can be used where the water supply is limited and on fields with variable topography that cannot be easily leveled to accommodate seep irrigation (Stanley and Maynard, 1990). In addition to being used for irrigation, sprinkler systems are often used to cool the crop, apply fertilizer and pesticide, and for frost control (Kidder and Davis, 1955)

\section{Microirrigation}

In the late 1960s, microirrigation (drip or trickle) systems were developed (Hall, 1971) and have slowly replaced many of the sprinkler and some of the seepage systems formerly used for vegetables. Microirrigation is currently used on 5\% of irrigated crops, principally on high value crops in areas where water availability is limited (Irrigation Journal, 2001). Water is applied through outlets (emitters) in low pressure hoses placed at close proximity to the crop in small amounts on a daily basis. Drip irrigation is widely used on polyethylene-mulched vegetables, particularly tomato (Locascio and Myers, 1974), pepper (Hartz et al., 1993), and strawberry (Myers and Locascio, 1972), and on unmulched and mulched cucurbits (Hochmuth et al., 1993). Drip irrigation requires much more management than other irrigation systems but it provides more options for precise control of water, nutrient, and pesticide applications. The major benefit of drip irrigation is the high water use efficiency $(90 \%$ to $95 \%$ ). Water use with drip irrigation is about one-third to one-half that with sprinkler irrigation (Locascio and Myers, 1974). For efficient use of drip irrigation, water and nutrient applications must be carefully managed.

Irrigation can be scheduled by replacing a portion of the water evaporated from a U.S. Weather Service Class A evaporation pan (pan) (Phene et al., 1973; Smajstrla et al., 2000) as a measure of evapotranspiration (ET). An excess of drip irrigation reduces yield of tomato (Locascio et al., 1989). Polyethylene-mulched tomato yields with drip irrigation at 2.0 pan were lower than with 1.0 pan (Locascio et al., 1981). In a spring crop on a coarse textured soil, yields were higher with 0.5 pan than 1.0 pan (Locascio et al., 1989) with a maximum yield produced above 0.5 pan and at about 0.75 pan (Locascio and Smajstrla, 1989). On a fine textured soil, tomato yields were similar with 0.5 and 1.0 pan water quantities (Locascio et al., 1989; Olson and Rhoads, 1992) with water use of 20 to $30 \mathrm{~cm}$ per crop. On both soils, yields were similar with one and three irrigation applications per day. Pitts and Clark (1991) found that tomato water requirements varied from 0.2 pan in early season to 0.8 pan during fruit development. Water scheduling by pan often overestimates early crop water needs. Less water is applied with tensiometer scheduling of water at 10 to $15 \mathrm{kPa}$ on a coarse textured soil. Water use on tomato was $30 \mathrm{~cm}$ per crop with water scheduled to replace 0.75 pan and $17 \mathrm{~cm}$ used where irrigation was scheduled with magnetic switching tensiometers to apply water to maintain soil at $10 \mathrm{kPa}$ (Locascio and Smajstrla, 1996; Smajstrla and Locascio, 1996). On finer textured soils, water is applied to maintain the soil at 20 to $50 \mathrm{kPa}$ (Locascio et al., 1992). In addition to tensiometers, soil water sensors that can be used to determine the time of irrigation include granular matrix sensors (GMS) (Eldredge et al., 1993) and time-domain reflectometry (TDR) (Topp et al., 1984).

With drip irrigation, soluble nutrients move with the wetting front. Overirrigation results in nutrient leaching 
and reduced yields (Bar-Yosef, 1977). Yields were similar with sprinkler and drip irrigation where all nutrients were applied preplant for tomato (Doss et al., 1980; Locascio and Myers, 1974) and watermelon (Citrullus lanatus) (Elmstrom et al., 1981). With part of the $\mathrm{N}$ and $\mathrm{K}$ applied with the drip irrigation water, yields were higher than with sprinkler irrigation for tomato (Locascio and Myers, 1974), muskmelon (Shmueli and Goldgerg, 1971), and strawberry (Locascio and Myers, 1975 ). With $100 \%$ preplant applied N and $\mathrm{K}$, tomato yields were lower than where $50 \%$ was applied with drip irrigation (Dangler and Locascio, 1990). On a coarse textured soil, application of all $\mathrm{P}$ and $40 \% \mathrm{~N}$ and K preplant with $60 \%$ $\mathrm{N}$ and $\mathrm{K}$ applied with drip irrigation as compared to all nutrients applied preplant resulted in increased tomato yields (Locascio and Smajstrla, 1989; Locascio et al., 1997). With $40 \%$ preplant $\mathrm{N}$ and $\mathrm{K}$, yields were similar with 6 bi-weekly or 12 weekly applications in either equal nutrient applications or with a variable nutrient schedule of small amounts early and larger amounts as plant growth progresses (Locascio et al., 1997) and with daily or weekly nutrient applications (Locascio and Smajstrla 1989). The use of drip irrigation has required changes in how fertilizer is applied. With drip irrigation on a coarse textured soil, it is essential for part of the $\mathrm{N}-\mathrm{K}$ to be applied with the drip system and to avoid overirrigation. With only a part of the nutrients applied at planting, nutrient leaching is reduced, nutrient use efficiency is increased and generally results in higher yields than with all nutrients applied preplant or through the drip system (Locascio et al., 1997). However, on fine textured soil, yields were higher with $100 \%$ preplant nutrients than with all or part of the nutrients drip applied (Locascio et al., 1997). Split applications of nutrients were reported on pepper (Hartz et al., 1993) and muskmelon (Bogle and Hartz, 1986) to provide maximum production.

Another use of drip is as a subsurface drip system (SDI) with tubes placed at a depth of 60 to $90 \mathrm{~cm}$ (below the plow zone). These systems are managed to control the water table similar to that accomplished with subsurface irrigation systems but with much greater water use efficiency as water supply ditches are eliminated. Use of this system is limited to soils that are poorly drained where a water table can be established (Phene, 1995). The SDI systems are buried and provide efficient use of water and nutrients, but in contrast to conventional drip systems, SDI can be used for several years, thereby reducing the cost of the system. These systems are suitable for process tomato (Phene et al., 1992), potato (DeTar et al., 1996), onions, lettuce, and pepper with irrigation frequencies of two times per week (Hanson et al., 2003).

Advantages of drip irrigation over sprinkler include reduced water use, ability to apply fertilizer throughout the season, precise water distribution, reduced foliar diseases, and reduced weed growth as plant foliage and row middles remain drier than with furrow or sprinkler irrigation. In addition to the application of water and nutrients, drip systems can be used to efficiently apply some pesticides, including nematicides (Overman, 1976).

Maximum yields with drip irrigation are produced with precise management of water and nutrients. However, systems are complex and include drip tubing, filters, pumps, back-flow prevention devices, injectors, and timers that require a high degree of maintenance and management. Because smaller amounts of water are applied daily with drip irrigation than with other irrigation systems, drip irrigation can be applied with a relatively smaller pump than overhead irrigation, resulting in reduced pumping cost (Prevatt et al., 1992). However, irrigation system costs are the most with drip systems ( $\$ 1200 / \mathrm{ha})$ and the least with subirrigation $(\$ 470 / \mathrm{ha})$.

Future irrigation concerns include the continued availability of adequate water for agriculture, management of nutrients to minimize leaching of nutrients into the groundwater, and continuing the development of cultural practices that maximize crop water use efficiency (Gollehon et al., 2002). Drip systems offer the opportunity to economically produce a crop where water is in short supply and very costly.

\section{Literature cited}

Bar-Yosef, B. 1977. Trickle irrigation and fertilization of tomatoes in sand dunes. Water, $\mathrm{N}$ and $\mathrm{P}$ distribution in the soil land uptake by plants. Agron. J. 69:486-491.

Bernstein, L. and L.E. Francois. 1973. Comparisons of drip, furrow, and sprinkler irrigation. Soil Sci. 115:73-86.
Bogle, C.R. and T.K. Hartz. 1986. Comparison of drip and furrow irrigation for muskmelon production. HortScience 21:242-244.

Dangler, J.M. and S.J. Locascio. 1990. Yield of trickle-irrigated tomatoes as affected by time of $\mathrm{N}$ and $\mathrm{K}$ application. J. Amer. Soc. Hort. Sci. 115:585-589.

DeTar, W.R., G.T. Browne, C.J. Phene, and B.L. Sanden. 1996. Real-time irrigation scheduling of potatoes with sprinkler and subsurface drip systems, p. 812-824. In: C.R. Camp, E.J. Sadler, and R.E. Yoder (eds.). Evapotranspiration and irrigation scheduling. Amer. Soc. Agr. Eng., San Antonio, Texas.

Doss, B.D., J.L. Turner, and C.E. Evans. 1980. Irrigation methods and in-row chiseling for tomato production. J. Amer. Soc. Hort. Sci. 105:611-614.

Eldredge, E.P., C.C. Shock, and T.E. Stieber. 1993. Calibration of granular matrix sensors for irrigation management. Agron. J. 85:1228-1232.

Ellis, J.E., E.G. Kruse, A.E. McSay, C.M.U. Neale, and R.A. Horn. 1986. A comparison of five irrigation methods on onions. HortScience 21:1349-1351.

Elmstrom, G.W., S.J. Locascio, and J.M. Myers. 1981. Watermelon response to drip and sprinkler irrigation. Proc. Fla. State Hort. Soc. 94:161-163.

Gollehon, N., W. Quinby, and M. Aillery. 2002. Agricultural resources and environmental indicators: Water use and pricing in agriculture. Econ. Res. Serv., U.S. Dept.Agr. 6 Jan. 05. http://www. ers.usda.gov/publications/arei/ah722/ arei2_1/DBGen.htm.

Hall, B.J. 1971. Comparison of drip and furrow irrigation for market tomato. Proc. Natl. Agr. Plastics Conf. 10:19-27.

Hanson, B.R., D.M. May, and L.J. Schwankl. 2003. Effect of irrigation frequency on subsurface drip irrigated vegetables. HortTechnology 13:115-120.

Hartz, T.K., M. LeStrange, and D.M. May. 1993. Nitrogen requirements of drip-irrigation pepper. HortScience 28:1097-1099.

Hochmuth, G.J., S.J. Locascio, T.E. Crocker, C.D. Stanley, G.A. Clark, and L.R. Parsons. 1993. Impact of microirrigation on Florida horticulture. HortTechnology 3:223-229.

Irrigation Journal. 2001. 2000 annual irrigation survey continues steady growth. Irr. J. Jan./Feb.:12-41.

Kidder, E.H. and J.R. Davis. 1955. Frost protection with sprinkler irrigation. Mich. Agr. Ext. Ser. Bul. 327. 
Locascio, S.J. and A.G. Smajstrla. 1989. Drip irrigated tomato as affected by water quantity and $\mathrm{N}$ and $\mathrm{K}$ application timing. Proc. Fla. State Hort. Soc. 102:307-309.

Locascio, S.J. and A.G. Smajstrla. 1996. Water application scheduling by pan evaporation for drip-irrigated tomato. J. Amer. Soc. Hort. Sci. 121:63-68

Locascio, S.J, G.A. Clark, A.A. Csizinszky, C.D. Stanley, S.M. Olson, F. Rhoads, A.G. Smajstrla, G. Vellidis, R.J. Edling, H.Y. Hanna, M.R. Goyal, S. Crossman, and A.A. Navarro. 1992. Water and nutrient requirements for drip-irrigated vegetables in humid regions. Fla. Agr. Expt. Stat. Bul. 363 .

Locascio, S.J., G.J. Hochmuth, F.M. Rhoads, S.M. Olson, A.G. Smajstrla, and E.A. Hanlon. 1997. Nitrogen and potassium application scheduling effects on drip-irrigated tomato yield and leaf tissue analysis. HortScience 32:230-235.

Locascio, S.J. and J.M. Myers. 1974. Tomato response to plug-mix mulch and irrigation method. Proc. Fla. State Hort. Soc. 87:126-130.

Locascio, S.J. and J.M. Myers. 1975. Trickle irrigation and fertilization method for strawberry. Proc. Fla. State Hort. Soc. 88:185-189.

Locascio, S.J., J.M. Myers, and S.R. Kostewicz. 1981. Quantity and rate of water application for drip irrigated tomatoes. Proc. Fla. State Hort. Soc. 94:163-166

Locascio, S.J., J.M. Myers, and J.G.A. Fiskell. 1982. Nitrogen application timing and source for drip irrigated tomatoes, $\mathrm{p}$. 323-328. In: A. Scaife (ed..) Proc. Ninth Intl. Plant Nutr. Colloq., Warwick Univ., U.K.

Locascio, S.J., S.M. Olson, and F.M. Rhoads. 1989. Water quantity and time of $\mathrm{N}$ and $\mathrm{K}$ application for trickle-irrigated tomatoes. J. Amer. Soc. Hort. Sci.114:265-268.
Myers, J.M. and S.J. Locascio. 1972. Efficiency of irrigation methods for strawberry. Proc. Fla. State Hort. Soc. 85:114-117.

Nonnecke, I.L. 1989. Vegetable production. Van Nostrand Reinhold, New York.

Myhre, D.L., S.F. Shih, and M.L. Whitehead. 1986. Soil salinity in an abandoned tomato field in Lee County, Florida. Soil Crop Sci. Soc. Fla. Proc. 45:41-46.

Olson, S.M. and F.M. Rhoads. 1992. Effect of water quantity on fall tomato production in north Florida. Proc. Fla. State Hort. Soc. 105:334-336.

Overman, A.J. 1976. Efficacy of soil fumigants applied via a drip irrigation system. Proc. Fla. State. Hort. Soc. 89:143-145.

Phene, C.J. 1995. The sustainability and potential of subsurface drip irrigation, $\mathrm{p}$. 359-367. In: F.R. Lamm (ed.). Microirrigation for a changing world: Conserving resources/preserving the environment. Proc. Fifth Intl. Microirr. Congr. Amer. Soc. Agr. Eng., Orlando, Fla.

Phene, C.J., G.J. Hoffman, and R.S. Austin. 1973. Controlling automated irrigation with a soil matric potential sensor. Trans. Amer. Soc. Agr. Eng. 16:773-776.

Phene, C.J., R.B. Hutmacker, and K.R. Davis. 1992. Two hundred tons per hectare of processing tomatoes-Can we reach it? HortTechnology 2:16-22.

Pitts, D.J. and G.A. Clark. 1991. Comparison of drip irrigation to subirrigation for tomato production in southwest Florida. Appl. Eng. Agr. 7:177-184.

Pitts, D.J., G.A. Clark, J. Alvarez, P.H. Everett, and J.M. Grimm. 1988. A comparison of micro to subsurface irrigation of tomatoes. Proc. Fla. State Hort. Soc. 101:393-397.

Prevatt, J.W., C.D. Stanley, and A.A. Csizinszky. 1981. An economic evaluation of three irrigation systems for tomato production. Proc. Fla. State Hort. Soc. 94:166-169.
Prevatt, J.W., G.A. Clark, and C.D. Stanley. 1992. A comparative cost analysis of vegetable irrigation systems. HortTechnology 2:91-94.

Sammis, T.W. 1980. Comparison of sprinkler, trickle, subsurface, and furrow irrigation methods for row crops. Agron. J. 72:701-704

Shmueli, M. and D. Goldberg. 1971. Sprinkle, furrow and trickle irrigation of muskmelon in an arid zone. HortScience 6:557-559.

Smajstrla, A.G. and S.J. Locascio. 1996. Automated drip irrigation scheduling of tomato using tensiometers, p. 845-850. In: C.R. Camp, E.J. Sadler, and R.E. Yoder (eds.). Evapotranspiration and irrigation scheduling. Amer. Soc. Agr. Eng., San Antonio, Texas.

Smajstrla, A.G., D.Z. Haman, and F.S. Zazueta. 1999. Irrigated acreage in Florida: A summary through 1998. Fla. Coop. Ext. Ser. Circ. 1220. Univ. of Fla., Gainesville.

Smajstrla, A.G., D.R. Hensel, D.S. Harrison, and F.S. Zazueta. 1984. Improved seepage irrigation efficiency by controlled water applications. Proc. Fla. State Hort. Soc. 97:187-187.

Smajstrla, A.G., F.S. Zazueta, G.A. Clark, and D.J. Pitts. 2000. Irrigation scheduling with evaporation pans. Fla. Coop. Ext. Serv. Bul. 254. Univ. of Fla., Gainesville.

Solley, W.B., R.R. Pierce, and H.A. Perlman. 1998. Estimated use of water in the U.S. in 1995. U.S. Geological Survey, U.S. Dept. of the Interior. Circ. 1200.

Stanley, C.D. and D.N. Maynard. 1990. Vegetables, p. 921-950. In: Irrigation of agricultural crops. ASA-CSSA-SSSA. Agronomy Monogr. No. 30.

Topp, G.C., J.L. Davis, W.G. Bailey, and W.D. Zebchuk. 1984. The measurement of soil water content using a portable TDR hand probe. Can. J. Soil Sci. 64:313-321. 